protein concentrate from petroleum hydrocarbons. The pioneer work in this field was done at Lavera, France, and for the last five years the Shell BP group has been engaged in a research and industrial programme aimed at protein production on an industrial scale, chiefly at Grangemouth, Scotland.

Protein concentrates can be made by two processes: the product is an off-white, free flowing, tasteless powder which has a relatively high lysine content but which is low in methionine. One process starts with refined petroleum hydrocarbons and the other with gas or diesel oil. These unusual substrates are fermented by yeast cells grown in conditions of favourable $p H$ and temperature and provided with adequate substrate and minerals. The fermented product is centrifuged and treated to produce a cream suitable for the drying stage. From each ton of hydrocarbon, a ton of protein concentrate is produced. This is suitable for use in animal foodstuffs and will possibly compete in food value and cost with more familiar protein concen. trates such as fish meal and soya. Laboratory and early field-scale testing of the nutritional value of the product is being supplemented by toxicological studies using albino rats. Stringent safeguards have to be satisfied before the protein can be used for human consumption, but it has been suggested that it could be included in bread and biscuits. Furthermore, the protein can be extracted and coagulated to form a material with a structure resembling meat such as veal or chicken.

These results are shortly to be published in detail in the Journal of General Petroleum.

\section{A Ship from the Bottom}

THE raising and restoration of the seventeenth century Swedish warship the Wasa is a strikingly brilliant piece of marine archaeology, and the small but informa. tive Wasa Exhibition at the Science Museum in London does it justice. The exhibition, organized by the Wasa Museum and the Swedish National Maritime Museum under the auspices of the Swedish Institute, traces the history of the ship from its construction and sinking on its maiden voyage in 1628 to the location of the hull in 1956 and its recovery in 1961.

The Wasa, for some unknown reason, capsized and sank before it had left Stockholm harbour. Most of the heavy cannons were recovered in the seventeenth century by divers using the most primitive of diving bells and the ship was then forgotten. In 1956, however, it was relocated at a depth of 100 feet, completely silted up with mud, and the Swedish Government decided to raise it. This posed enormous technical difficulties which have been brilliantly overcome. The exhibition shows with models and photographs how the hull was lifted in seventeen stages until it was at a depth of 60 feet and finally raised to the surface in April 1961.

Once on the surface, 1,000 cubic metres of mud was removed and sifted, yielding about 24,000 objects including clothing (see illustration), food, coins, sails and utensils. From these an authentic picture of life aboard a seventeenth century warship can be reconstructed. The woodwork of the hull was remarkably well preserved as several photographs and replicas show. Fortunately, the salinity in the Baltic is too low for wood boring animals such as Teredo and this more than anything else accounts for the good state of the woodwork.

Preservation of the hull is an enormous task which is still going on. It is the largest water-logged object ever to be preserved and the Swedish authorities are sparing neither time nor expense to make sure it is done properly. To prevent the wood from shrinking as it dries out it is being impregnated with polyethylene glycol. All the movable parts are being stewed in a 60 per cent solution at $60^{\circ} \mathrm{C}$ and then carefully dried. The main bulk of the hull-190 feet long-is being continuously sprayed with polyethylene glycol solution and this operation will not be completed until 1971. It will then be dried out under carefully controlled humidity and eventually all the pieces reassembled.

\section{Sorry, for copyright reasons some images on this page may not be available online}

\footnotetext{
The seaman's clothing on this model was recovered from the hull of the Wasa. (Science Museum photograph.)
}

The exhibition, which whets the appetite for the real thing, will stay in England until 1969 during which time it will be shown at most provincial museums. Similar exhibitions are touring North America, Australasia and the continent of Europe.

\section{Irradiating Food}

Some estimates indicate that as much as 20 per cent of the world food supply is wasted by spoilage-in some areas this figure may reach 50 per cent. Clearly any technique for reducing this waste would be welcome, which explains the considerable interest in food preservation by irradiation. One investigation of this sort is being carried out under an agreement between the Austrian Atomic Energy Agency, the European Nuclear Energy Agency and the International Atomic Energy Agency. The work is done at the Reactor Centre at Seibersdorf in Austria, and the project has just published details of progress up to the end of 1966. 
The report shows that the project has been slow to get off the ground. In 1960, the ENEA set up a committee to examine the feasibility of the process; in 1961 Austria indicated willingness to do the experimental work, on fruit and fruit juices. In 1962 the draft programme was drawn up; in 1963 a draft agreement was submitted, and it was finally signed in September 1964. Work began in January 1965, but the irradiation facility was not finished until September this year. Initially work will be concentrated on fruit juices, both because of their convenience and because the yeasts which are mainly responsible for the spoilage of fruit juice are a well studied group of micro-organisms. The experimental work is divided into three main fields: radiosensitization studies on yeasts and moulds, technological studies including radiation chemistry and wholesomeness tests.

Like other methods of food preservation-smoking, drying, canning or freezing-irradiation affects the taste of the food. Results at Seibersdorf with grape juice have not yet established which compound is responsible for irradiation taste, but the indications are that the undesirable taste is not caused by protein degradation. Some evidence indicates that flavour changes can be minimized by irradiation at very high dose rates, and preliminary results from work in Switzerland with an accelerator indicate that apple juice can tolerate a high dose rate without significant flavour change. Of rather more importance is the work necessary to establish that the new process is safe for human consumption over long periods. At Seibersdorf animal feeding trials are being made with three types of animals-rats, mice and miniature pigs.

Work with apple juice has established that only one compound, furan or a furan derivative, was specifically produced by the irradiation process. But compounds already present in the unirradiated juice, like acetaldehyde, may be increased. The concentration of acetaldehyde continues to increase during storage, while cupronaldehyde, present after irradiation, appears to decline in concentration during storage. The irradiated apple juice, the report says, could be stored successfully at room temperature for 200 days.

\section{Architects and Engineers}

THE building industry has for a long time been troubled by differences that exist between the members of the various professions that work together in a building team. Architects and engineers have tended to become isolated from one another because of differences in their professional training. An attempt is now being made to find ways of breaking down the barriers between them, so that the skills and total knowledge of individuals can be used more effectively than at present. A joint education group was set up in 1966 by the Council of Engineering Institutions (CEI) and the Royal Institute of British Architects (RIBA) to find ways of improving the understanding during training between the disciplines of architecture and engineering, and to consider the possibility of training people to be both engineers and architects. The nine-strong group of two architects, four engineers and three RIBA staff has just produced its interim report, which covers the first of these problems and gives a preliminary statement of the second.

Much of the present lack of communication between architects and engineers is caused by differences in the educational systems. Both professions require at least six years' training, but the academic content varies. Engineers take a three-year academic course followed by three years' practical training, while architects have a year of practical training after their third year, in the middle of their academic course, so that theory and practice are interwoven. But the most fundamental difference is in the approaches of the professions. Engineers are given highly technical training with little concern for the human side of the problems. Architects, on the other hand, consider the human factor to be of prime importance, but are sometimes short on technical expertise. Some subjects that are common to both disciplines have up to now been treated differently. In structures, for example, architects are concerned with strategy, and engineers with tactics. This means that architects study the causes and effects of certain choices, while engineers are there to see that the choice which is finally made stays up. Despite his greater technical knowledge, the engineer must leave design to the architect.

The problems of communication are not new, but there are now signs of progress. The CEI, which represents the majority of the engineering institutions, is aiming to provide a common theoretical basis for all engineers which can then be applied to any specialist field. This approach does not encourage integration with architecture, but the fact that the CEI is involved on the education project indicates its awareness of the situation. The Council for National Academic Awards, which awards degrees to students at polytechnics, has the power to accept or reject courses into the degree category. It therefore has considerable influence on the content of non-university courses. The group has several suggestions to make for increasing understanding and co-operation, based on the idea of students working together. Project work could be carried out by architecture and engineering students together, and some parts of the syllabus could be shared. The group believes that "orientation" courses for engineers entering the building field are worth investigating. Teachers from one discipline who appreciate the problems of the other could also help. The ultimate solution as described by the group rests on the establishment of educational institutions where architects and building engineers can work together. This would require engineers to commit themselves to the building field at an early stage-to good purpose, the group thinks.

\section{Free Enterprise under the Sea}

AmIDst all the rumours of new Government support for oceanography in Britain, it is refreshing to find some young men who are prepared to back their hunches and build for the future under the sea without waiting for the cat to jump.

At Lintott Engineering Ltd's Horsham works last week, Britain's first mobile submersible was given its first demonstration. Called SURV, for Standard Underwater Research Vessel, it was initially the concept and design of M. J. Borrow, R. E. Lloyd and J. M. Metcalf of Underwater and Marine Operations Ltd (Woking), who have seen it through to the fully engineered prototype constructed by Lintott and demonstrated last week after two months of sea trials. 